\title{
Screening of arbuscular endomycorrhizal fungi for establishment of micropropagated pineapple plants
}

\author{
JP Guillemin, S Gianinazzi *, A Trouvelot \\ INRA-CNRS, laboratoire de Phytoparasitologie, Station de Génétique et d'Amélioration des Plantes, \\ INRA, BV 1540, 21034 Dijon cédex, France
}

(COST Meeting, 21-23 May 1992, Dijon, France)

\begin{abstract}
Summary - Several arbuscular endomycorrhizal fungi (Glomus clarum (LPA16), Scutellospora pellucida (LPA20), Glomus sp. (LPA21), Glomus sp (LPA22) and Glomus sp (LPA25)) were tested for plant growth effects and infection development in Queen Tahiti, Smooth Cayenne (clone $\mathrm{CY}_{0}$ ) and Spanish varieties of micropropagated pineapple growing in an acid soil under growth chamber tropical conditions. Endomycorrhizal plants of all 3 pineapple varieties grew better than non-mycorrhizal plants. However, increase in plant growth was not related to infection development. Screening of different isolates of arbuscular endomycorrhizal fungi showed some specificity of fungi for promoting growth of the different pineapple varieties. Queen Tahiti and Smooth Cayenne pineapple plants associated with Glomus sp (LPA21) grew better than those infected with the other fungi, whilst best growth was obtained for the Spanish variety by inoculating plants with Glomus $\mathrm{sp}$ (LPA25). The root/shoot ratio was modified by endomycorrhizal inoculation, infected pineapple plants showing a greater increase in shoot production in comparison to root production.
\end{abstract}

micropropagated pineapple / arbuscular endomycorrhizal fungi / plant growth / infection development

\begin{abstract}
Résumé - Sélection de champignons endomycorhizogènes à arbuscules efficients pour l'établissement d'ananas micropropagés. Plusieurs champignons endomycorhizogènes à arbuscules (Glomus clarum (LPA 16$)$, Scutellispora pellucida (LPA20), Glomus sp (LPA21), Glomus sp (LPA22) and Glomus sp (LPA25)) ont été testés pour leur développement et leur effet sur la croissance de 3 variétés d'ananas micropropagés (Queen Tahiti, Cayenne lisse (clone CYO) et Spanish) cultivés dans un sol acide et dans une salle climatisée aux conditions tropicales. Pour les 3 variétés d'ananas testées, les vitroplants endomycorhizés présentent une meilleure croissance que les non inoculés. Cependant l'augmentation de croissance n'est pas liée avec l'importance de l'infection. La sélection des différents champignons endomycorhizogènes montrent une certaine spécificité fongique vis à vis des différentes variétés d'ananas. Ainsi les vitroplants des variétés Queen Tahiti et Cayenne lisse, associés avec Glomus sp (LPA21), présentent une meilleure croissance que ceux infectés avec les autres champignons tandis que la meilleure croissance pour la variété Spanish a été obtenue avec Glomus sp (LPA25). Le rapport du poids de matière fraîche racinaire sur le poids de matière fraîche aérienne est modifié par la présence de champignons endomycorhizogènes; l'effet endomycorhizien sur la croissance de la partie aérienne est supérieur à celui obtenu sur la partie racinaire des vitroplants.
\end{abstract}

ananas micropropagés / champignons endomycorhizogènes à arbuscules / croissance de la plante-hôte / infection endomycorhizienne

\section{INTRODUCTION}

Micropropagation is a technique of increasing importance for the production of many crops (Sasson, 1992). This includes pineapples which form arbuscular endomycorrhiza (Mourichon, 1981) as do nearly all cultivated plants (Powell and Bagyaraj, 1984; Gianinazzi et al, 1990). Endomycorrhization can modify root architecture to give a root system which is better adapt- ed for uptake of mineral nutrient and water (Berta et al, 1990), as well as increasing hormone production (Allen, 1985) and resistance to pesticides or root pathogens (Gianinazzi et al, 1982; Harley and Smith, 1983). Endomycorrhizal formation is suppressed by practices employed in micropropagation, and it is thus important to consider introducing symbiotic fungi during plant production. However, arbuscular endomycorrhizal fungi differ in their ability to enhance plant

* Correspondence and reprints 
growth, and to optimise yields it is necessary to screen for the most efficient isolates before developing mass inoculation (Haas and Krikun, 1985). Abbott and Robson (1978) suggested that characteristics of effective isolates are to infect roots rapidly and to efficiently translocate nutrients to plants.

Previous studies on the Smooth Cayenne (clone CY0) variety of pineapple showed that infection with the arbuscular endomycorrhizal fungus Glomus sp (LPA21) improved growth under simulated tropical conditions (Guillemin et al, 1991). The present paper reports a series of experiments carried out to compare the effect of several arbuscular endomycorrhizal fungi on plant growth and infection development in several varieties of micropropagated pineapple.

\section{MATERIALS AND METHODS}

Three micropropagated pineapple varieties (Queen Tahiti, Smooth Cayenne (clone CYO) and Spanish) were each inoculated with 1 of 5 arbuscular endomycorrhizal fungi : Glomus clarum (LPA16), Scutellispora pellucida (LPA20), Glomus sp (LPA21), Glomus sp (LPA22) and Glomus sp (LPA25).

Experiments were carried out in an acid soil $(\mathrm{pH}$ $5.0)$ under simulated tropical conditions $\left(300 \mu \mathrm{E} . \mathrm{s}^{-1}\right.$ $\mathrm{m}^{-2}, 28-25^{\circ} \mathrm{C}, 12 \mathrm{~h}$ day and $70-90 \%$ relative humidity). Pineapple microplants were inoculated during a post vitro acclimatization period with root fragments of Tephrosia ehlenbergiana infected by one of the fungal isolates (Guillemin et al, 1991). One $\mathrm{g}$ of infected roots was used to inoculate 10 microplants. After 1 month, pineapple plants were transplanted individually to pots containing $400 \mathrm{~g}$ of soil: gravel mix $(1: 1, \mathrm{v}: \mathrm{v})$. Each pot was watered daily with distilled water and weekly with $2 \times 20 \mathrm{ml}$ Hoagland No 2 solution (Hoagland and Arnon, 1950) without phosphate. After 3 months, growth was evaluated via several parameters: leaf area $\left(\mathrm{cm}^{2}\right)$, shoot and root fresh mass $(\mathrm{g})$ and shoot dry mass $(\mathrm{g})$.

Infection development was estimated by the method of Trouvelot et al (1986) after clearing and staining with trypan blue (Philipps and Hayman, 1970). Roots of the Spanish variety were stained also for succinate dehydrogenase (SDH) (Smith and GianinazziPearson, 1990) and alkaline phosphatase (ALP) (Tisserant et al, 1992) activity in order to evaluate living (SDH) and functional (ALP) fungal infections.

Each treatment comprised 5 replicates and all data was analysed by ANOVA and Newman-Keuls test.

\section{RESULTS}

\section{Plant growth}

Endomycorrhizal plants of all 3 pineapple varieties grew better than non-mycorrhizal plants. However, there were differences among the combinations of plant varieties and fungal isolates.

Optimum growth of Queen Tahiti (table I) and Smooth Cayenne varieties (table II) was obtained with Glomus sp (LPA21); leaf area and shoot fresh and dry mass were significantly higher than those of non-mycorrhizal plants. Both varieties infected with $G$ clarum (LPA16) also had a significantly higher leaf area.

Spanish variety responded to inoculation with all 5 fungi, with significant effects on all plant growth parameters (table III). Largest increases in shoot growth were obtained with Glomus $\mathrm{sp}$

Table I. Leaf area, shoot and root fresh mass and shoot dry mass of uninoculated and endomycorrhizal (Glomus clarum(LPA16), Scutellispora pellucida (LPA20), Glomus sp (LAP21), Glomus sp (LPA22) and Glomus sp (LPA25)) plants of the Queen Tahiti pineapple variety.

\begin{tabular}{llccc} 
Fungal strains & $\begin{array}{c}\text { Leaf area } \\
\left.(\mathrm{cm})^{2}\right)\end{array}$ & $\begin{array}{c}\text { Shoot fresh mass } \\
(g)\end{array}$ & $\begin{array}{c}\text { Root fresh mass } \\
(g)\end{array}$ & $\begin{array}{c}\text { Shoot dry mass } \\
(g)\end{array}$ \\
\hline Control & $249.2^{\mathrm{c}}$ & $21.03^{\mathrm{b}}$ & $1.90^{\mathrm{a}}$ & $2.27^{\mathrm{b}}$ \\
Glomus clarum (LPA16) & $444.3^{\mathrm{ab}}$ & $36.05^{\mathrm{ab}}$ & $2.42^{\mathrm{a}}$ & $4.26^{\mathrm{ab}}$ \\
Scutellospora pellucida (LPA20) & $363.8^{\mathrm{abc}}$ & $30.05^{\mathrm{ab}}$ & $1.98^{\mathrm{a}}$ & $3.61^{\mathrm{b}}$ \\
Glomus sp (LPA21) & $514.4^{\mathrm{a}}$ & $41.57^{\mathrm{a}}$ & $3.21^{\mathrm{a}}$ & $4.57^{\mathrm{a}}$ \\
Glomus sp (LPA22) & $445.5^{\mathrm{ab}}$ & $35.05^{\mathrm{ab}}$ & $2.56^{\mathrm{a}}$ & $4.15^{\mathrm{ab}}$ \\
Glomus sp (LPA25) & $298.0^{\mathrm{bc}}$ & $24.75^{\mathrm{ab}}$ & $2.42^{\mathrm{a}}$ & $2.85^{\mathrm{b}}$
\end{tabular}


Table II. Leaf area, shoot and root fresh mass and shoot dry mass of uninoculated and endomycorrhizal (Glomus clarum (LPA16), Scutellospora pellucida (LPA20), Glomus sp (LPA21), Glomus sp (LPA22) and Glomus sp (LPA25)) plants of the Smooth Cayenne pineapple variety.

\begin{tabular}{|c|c|c|c|c|}
\hline Fungal strains & $\begin{array}{l}\text { Leaf area } \\
\left(\mathrm{cm}^{2}\right)\end{array}$ & $\begin{array}{l}\text { Shoot fresh mass } \\
\text { (g) }\end{array}$ & $\begin{array}{l}\text { Root fresh mass } \\
\text { (g) }\end{array}$ & $\begin{array}{c}\text { Shoot dry mass } \\
(g)\end{array}$ \\
\hline Control & $413.7^{b}$ & $32.79^{b}$ & $3.46^{\mathrm{ab}}$ & $2.95^{a}$ \\
\hline Glomus clarum $\left(\mathrm{LPA}_{16}\right)$ & $607.4^{a}$ & $48.82^{\mathrm{a}}$ & $3.98^{\mathrm{ab}}$ & $4.22^{a}$ \\
\hline Scutellispora pellucida $\left(\mathrm{LPA}_{20}\right)$ & $473.0^{a b}$ & $38.39^{b}$ & $2.94^{b}$ & $3.36^{a}$ \\
\hline Glomus sp $\left(\mathrm{LPA}_{21}\right)$ & $640.1^{a}$ & $51.07^{a}$ & $4.18^{a}$ & $4.26^{a}$ \\
\hline Glomus sp (LPA $\left.{ }_{22}\right)$ & $515.9^{a b}$ & $41.13^{a b}$ & $2.80^{\mathrm{b}}$ & $3.68^{a}$ \\
\hline Glomus sp (LPA $\left.{ }_{25}\right)$ & $494.7^{a b}$ & $34.78^{b}$ & $3.18^{a b}$ & $3.98^{a}$ \\
\hline
\end{tabular}

Values in a column followed by different letters are significantly different $(P<0.05)$.

Table III. Leaf area, shoot and root fresh mass and shoot dry mass of uninoculated and endomycorrhizal (Glomus clarum (LPA16), Scutellospora pellucida (LPA20), Glomus sp (LPA21), Glomus sp (LPA22) and Glomus sp (LPA25)) plants of the Spanish pineapple variety.

\begin{tabular}{|c|c|c|c|c|}
\hline Fungal strains & $\begin{array}{l}\text { Leaf area } \\
\qquad\left(\mathrm{cm}^{2}\right)\end{array}$ & $\begin{array}{l}\text { Shoot fresh mass } \\
(g)\end{array}$ & $\begin{array}{l}\text { Root fresh mass } \\
(g)\end{array}$ & $\begin{array}{c}\text { Shoot dry mass } \\
(g)\end{array}$ \\
\hline Uninoculated & $311.4^{d}$ & $21.70^{d}$ & $2.27^{d}$ & $2.05^{d}$ \\
\hline Glomus clarum (LPA16) & $537.1^{\mathrm{b}}$ & $37.06^{a b}$ & $3.69^{a}$ & $3.64^{a b}$ \\
\hline Scutellispora pellucida (LPA20) & $519.7^{b}$ & $36.84^{a b}$ & $3.59^{a}$ & $3.81^{a b}$ \\
\hline Glomus sp (LPA21) & $539.1^{b}$ & $38.46^{a b}$ & $3.77^{a}$ & $3.71^{\mathrm{ab}}$ \\
\hline Glomus sp (LPA22) & $411.7^{c}$ & $27.60^{\mathrm{C}}$ & $2.81^{b}$ & $2.75^{\mathrm{c}}$ \\
\hline Glomus sp (LPA25) & $620.7^{a}$ & $43.37^{a}$ & $3.50^{\mathrm{a}}$ & $4.27^{a}$ \\
\hline
\end{tabular}

Values in a column followed by different letters are significantly different $(P<0.05)$.

(LPA25), whilst effects on root growth were similar for G clarum (LPA16), Scutellispora pellucida (LPA20), Glomus sp (LPA21) and Glomus sp (LPA25). The Glomus sp (LPA22) was generally less effective in improving plant growth.

\section{Root/shoot ratio}

Root/shoot ratios were modified by inoculation with arbuscular endomycorrhizal fungi (fig 1) and were generally lower than in non-mycorrhizal plants, with the exception of Queen Tahiti infected with Glomus sp (LPA25) (fig 1A) which was also the least effective isolate for growth of this pineapple variety. The endomycorrhizal effect on leaf area was negatively correlated $(P=0.05)$ with the endomycorrhizal effect on root/shoot ratio for Spanish variety but not for Queen Tahiti and Smooth Cayenne varieties (fig 2).

\section{Infection development}

Levels of infection observed with trypan blue staining differed between isolates (tables IV, V) but were not related to growth increases in any of the inoculated plants. Endomycorrhizal infection intensity $(\mathrm{M} \%)$ for the Spanish variety by $\mathrm{SDH}$ staining (table $\mathrm{V}$ ) was significantly lower with the fungal isolate LPA22. This isolate also gave a lower arbuscular frequency $(A \%)$, evaluated by both SDH and ALP staining, than the other isolates (table $\mathrm{V}$ ). 
A
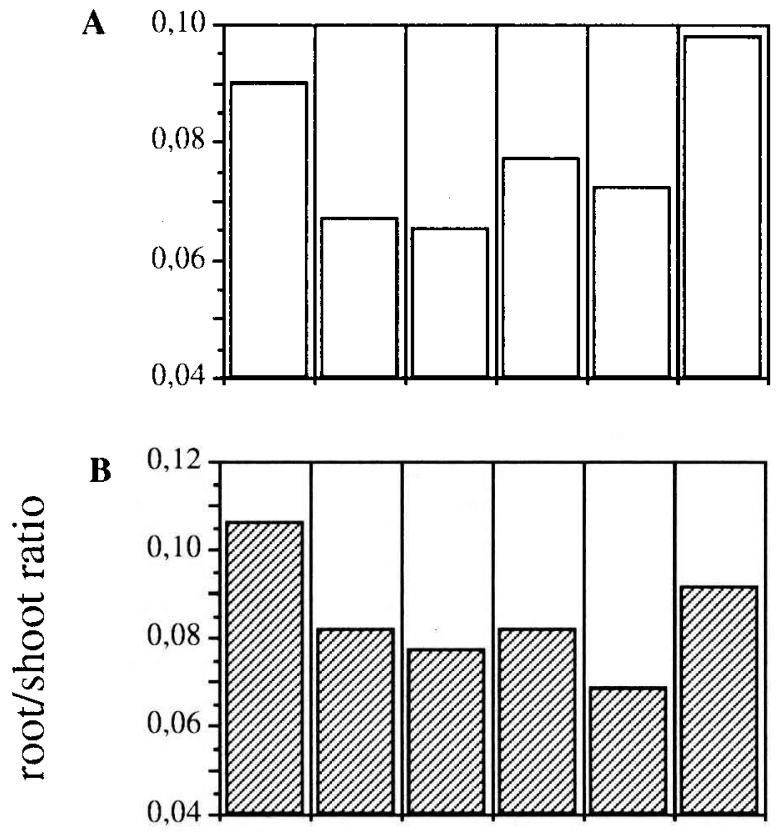

C

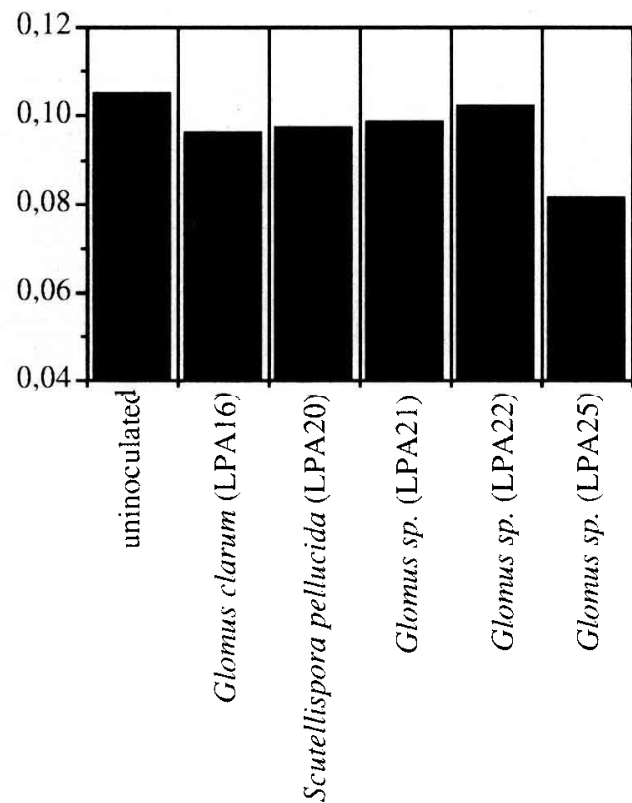

Fig 1. Root/shoot ratio of uninoculated and endomycorrhizal (Glomus clarum (LPA16), Scutellispora pellucida (LPA20), Glomus sp (LPA21), Glomus sp (LPA22) and Glomus sp (LPA25) plants of Queen Tahiti (A), Smooth Cayenne (B) and Spanish (C) pineapple varieties.

\section{DISCUSSION AND CONCLUSION}

Screening of different arbuscular endomycorrhizal fungi for their growth-promoting effects on 3 pineapple varieties indicated some specificity of isolates. Of the fungal isolates tested, Glomus sp (LPA21) appeared to be most effective for growth of the Queen Tahiti and Smooth Cayenne varieties of pineapple, and Glomus $\mathrm{sp}$
A
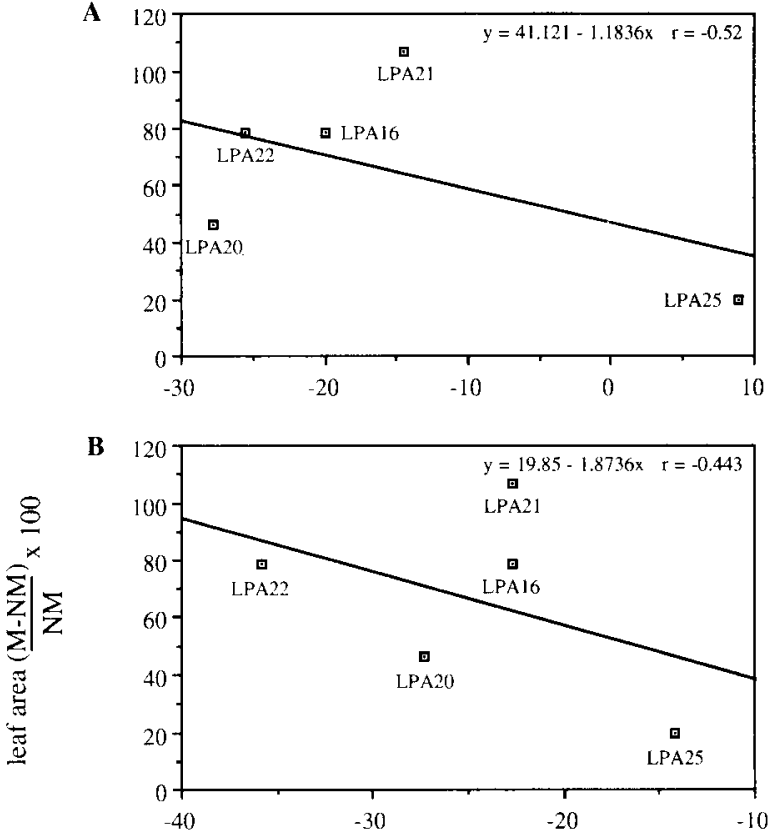

C

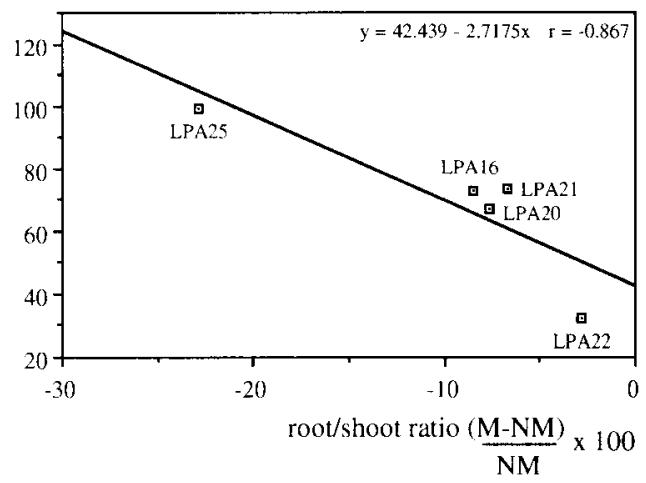

Fig 2. Negative correlations between endomycorrhizal effects on leaf area and on root/shoot ratio of Queen Tahiti (A), Smooth Cayenne (B) and Spanish (C) pineapple varieties.

(LPA25) for the Spanish variety. These observed differences in effectivity underline the necessity to select arbuscular endomycorrhizal fungal isolates. However, these tests were carried out under conditions without competition from other fungi. If such results are to be translated into field predictions, it is necessary to know whether these efficient fungi are also able to establish and persist in the presence of competition by indigenous arbuscular endomycorrhizal fungi (Powell, 1982). Furthermore, it would be of interest to test whether inoculating with a mixture of fungal isolates is more efficient in promoting the growth of different pineapple varieties than inoculation with individual fungal isolates. Sieverding (1989), however, has suggested that it would be more interesting to find one isolate that is effective with a wide range of plant species, since interactions can occur between different isolates in mixtures. 
Table IV. Percent endomycorrhizal infection (M\%: intensity of infection and A\%: arbuscule frequency) observed with trypan blue staining in roots of uninoculated and endomycorrhizal (Glomus clarum (LPA16), Scutellospora pellucida (LPA20), Glomus sp (LPA21), Glomus sp (LPA22) and Glomus sp (LPA25)) plants of Queen Tahiti and Smooth Cayenne pineapple variety.

\begin{tabular}{lcccc}
\hline \multirow{2}{*}{ Fungal strains } & \multicolumn{2}{c}{ Queen Tahiti } & & \multicolumn{2}{c}{ Smooth Cayenne } \\
\cline { 2 - 5 } & M\% & A\% & M\% & $A \%$ \\
\cline { 2 - 5 } & & & $0^{\mathrm{c}}$ & $0^{\mathrm{d}}$ \\
Uninoculated & $0^{\mathrm{d}}$ & $0^{\mathrm{d}}$ & $87^{\mathrm{a}}$ & $69^{\mathrm{a}}$ \\
Glomus clarum (LPA16) & $74^{\mathrm{c}}$ & $36^{\mathrm{c}}$ & $71^{\mathrm{b}}$ & $40^{\mathrm{c}}$ \\
Scutellospora pellucida (LPA20) & $82^{\mathrm{b}}$ & $54^{\mathrm{b}}$ & $79^{\mathrm{b}}$ & $58^{\mathrm{b}}$ \\
Glomus sp (LPA21) & $91^{\mathrm{a}}$ & $69^{\mathrm{a}}$ & $83^{\mathrm{ab}}$ & $68^{\mathrm{a}}$ \\
Glomus sp (LPA22) & $92^{\mathrm{a}}$ & $71^{\mathrm{a}}$ & $89^{\mathrm{a}}$ & $57^{\mathrm{b}}$ \\
Glomus sp (LPA25) & $87^{\mathrm{ab}}$ & $53^{\mathrm{b}}$ & & \\
\hline
\end{tabular}

Values in a column followed by different letters are significantly different $(P<0.05)$.

Table V. Percent endomycorrhizal infection (M\%: intensity of infection and $A \%$ : arbuscule frequency) observed with trypan blue, succinate dehydrogenase $(\mathrm{SDH})$ and alkaline phosphatase (APL) staining in roots of uninoculated and endomycorrhizal (Glomus clarum (LPA16), Scutellospora pellucida (LPA20), Glomus sp (LPA21), Glomus sp (LPA22) and Glomus sp (LPA25)) plants of Spanish pineapple variety.

\begin{tabular}{|c|c|c|c|c|c|c|}
\hline \multirow[t]{2}{*}{ Fungal strain } & \multicolumn{2}{|c|}{ Trypan blue } & \multicolumn{2}{|c|}{$S D H$} & \multicolumn{2}{|c|}{$A L P$} \\
\hline & $M \%$ & $A \%$ & $M \%$ & $A \%$ & $M \%$ & $A \%$ \\
\hline Control & $\mathrm{OC}^{\mathrm{C}}$ & $\mathrm{O}^{\mathrm{c}}$ & Od & $o^{c}$ & $a^{b}$ & $\mathrm{od}^{\mathrm{d}}$ \\
\hline Glomus clarum (LPA16) & $74^{\mathrm{ab}}$ & $36^{a}$ & $51^{a}$ & $22^{a}$ & $36^{a}$ & $17^{a}$ \\
\hline Scutellospora pellucida (LPA20) & $70^{b}$ & $35^{a}$ & $52^{a}$ & $19^{a}$ & $32^{a}$ & $15^{b}$ \\
\hline Glomus sp (LPA21) & $85^{\mathrm{ab}}$ & $40^{a}$ & $54^{a}$ & $22^{a}$ & $35^{a}$ & $14^{b}$ \\
\hline Glomus sp (LPA22) & $92^{\mathrm{a}}$ & $33^{a}$ & $36^{c}$ & $13^{b}$ & $30^{\mathrm{a}}$ & $10^{c}$ \\
\hline Glomus sp (LPA25) & $69^{b}$ & $35^{a}$ & $43^{b}$ & $20^{a}$ & $33^{a}$ & $14^{b}$ \\
\hline
\end{tabular}

Values in a column followed by different letters are significantly different $(P<0.05)$.

The root/shoot ratio of pineapples $\left(\mathrm{a} \mathrm{C}_{4} / \mathrm{CAM}\right.$ plant) was decreased by endomycorrhizal infection, so that endomycorrhizal plants showed a greater increase in shoot production than root production. Such modifications in biomass distribution have often been observed in $\mathrm{C}_{3}$ plants (Harley and Smith, 1983; Gianinazzi and Gianinazzi-Pearson, 1986; Schubert and Hayman, 1986). The root/shoot ratio was negatively correlated with the endomycorrhizal effect on growth of the 3 varieties of pineapple, but this correlation was less important for the Queen Tahiti and Smooth Cayenne varieties (figs $2 A, B$ ). Although endomycorrhizal growth effects were greatest in these 2 varieties when infected with Glomus sp
$\left(\mathrm{LPA}_{21}\right)$, this arbuscular endomycorrhizal fungus induced a proportionally greater root production in comparison to the other fungi tested.

Levels of infection observed with trypan blue staining were not related to increased plant growth in any of the 3 varieties. However, the lower SDH and ALP activities present in roots of the Spanish variety may partly explain the lower growth responses in these plants. However, Vierheilig and Ocampo (1989) have suggested that SDH activity does not indicate the efficiency of an arbuscular endomycorrhizal fungus in promoting plant growth. The efficiency of a fungus for the enhancement of plant growth could perhaps be better assessed by ALP activity in endo- 
mycorrhizal roots (Tisserant et al, 1992). For a better understanding of the physiological basis of variations in the effectivity of arbuscular endomycorrhizal fungi, other parameters should also be analysed, such as external hypha production (network around the roots) (Abbott and Robson, 1985 ), longevity of hyphae in soil (Syivia, 1988), efficiency of uptake and transport of phosphorus to the host roots (Sylvia and Burks, 1988; Jakobsen et al, 1992), and interactions between external hyphae and mycophagous invertebrates (Rabatin and Stinner, 1991).

\section{ACKNOWLEDGMENTS}

The authors thank Vitropics (Montpellier, France) for supplying the micropropagated plant material and $\checkmark$ Gianinazzi-Pearson for valuable discussions and revision of the manuscript.

\section{REFERENCES}

Abbott LK, Robson AD (1978) Growth of subterranean clover in relation to formation of endomycorrhizas by introduced and indigenous fungi in a field soil. New Phytol 81, 575-585

Abbott LK, Robson AD (1985) Formation of external hyphae in soil by four species of vesicular-arbuscular mycorrhizal fungi. New Phytol 99, 245-255

Allen MF (1985) Phytohormone action : an integrative approach to understanding diverse mycorrhizal responses. In: Proc 6th $N$ Am Conf Mycorrhizae (R Molina, ed) For Sci Lab, Corvallis, OR, 158-160

Berta G, Fusconi A, Trotta A, Scannerini S (1990) Morphogenetic modifications induced by the mycorrhizal fungus Glomus strain $E_{3}$ in the root system of Allium porrum L. New Phytol 114, 207-215

Gianinazzi S, Gianinazzi-Pearson V (1986) Connaissances actuelles des bases physiologiques et biochimiques des effets des endomycorhizes sur le comportement des plantes. Physiol Vég 24, 253-262

Gianinazzi S, Gianinazzi-Pearson V, Trouvelot A (1982) Les Mycorhizes, Partie Intégrante de la Plante : Biologie et Perspective d'Utilisation. Coll INRA, No 13, INRA, Paris

Gianinazzi S, Trouvelot A, Gianinazzi-Pearson V (1990) Role and use of mycorrhizas in horticultural crop production. In : 23 IHC Plenary Lectures. Int Soc Hortic Sci, Florence, Italy, 25-30

Guillemin JP, Gianinazzi S, Gianinazzi-Pearson V (1991) L'endomycorhization de vitroplants d'Ananas comosus : mise en évidence d'un effet mycorhizien. Fruits 46 (spéc Ananas), 355-358

Haas JH, Krikun J (1985) Efficacy of endomycorrhizal fungus isolates and inoculum quantities required for growth response. New Phytol 100, 613-621
Harley JL, Smith SE (1983) Mycorrhizal Symbiosis. Academic Press Inc, London

Hoagland DR, Arnon DI (1950) The water-culture method for growing plants without soil. Circ Calif Agric Exp Stn No 347

Jakobsen I, Abbott LK, Robson AD (1992) External hyphae of vesicular-arbuscular mycorrhizal fungi associated with Trifolium subterraneum L. 2. Hyphal transport of ${ }^{32} \mathrm{P}$ over defined distances. New Phytol $120,509-516$

Mourichon X (1981) Mise en évidence d'une association endomycorhizogène chez l'ananas en Côte d'Ivoire. Fruits 36 (12), 745-749

Philipps JM, Hayman DS (1970) Improved procedures for clearing roots and staining parasitic and vesicular-arbuscular mycorrhizal fungi for rapid assessment of infection. Trans Br Mycol Soc 55, 158-161

Powell CL (1982) Selection of efficient VA mycorrhizal fungi. Plant Soil 68, 3-9

Powell CL, Bagyaraj DJ (1984) VA Mycorrhiza. CRC Press, Inc, Boca Raton, FL

Rabatin SC, Stinner BR (1991) Vesicular-arbuscular mycorrhizae, plant, and invertebrate interactions in soil. In : Microbial Mediation of Plant-Herbivore Interaction (Barbosa P, Krischik VA, Jones CG, eds) John Wiley and Sons inc, NY, 141-168

Sasson A (1992) La micropropagation des plantes : réalité et priorité. Biofutur 111, 34-38

Schubert A, Hayman DS (1986) Plant growth responses to vesicular-arbuscular mycorrhiza. XVI. Effectiveness of different endophytes at different levels of soil phosphate. New Phytol 103, 79-90

Sieverding E (1989) Should VAM inocula contain single or several fungal species? Agric Ecosystems Environ 29, 391-396

Smith SE, Gianinazzi-Pearson V (1990) Phosphate uptake and vesicular-arbuscular activity in mycorrhizal Allium cepa L: effect of photon irradiance and phosphate nutrition. Aust J Plant Physiol 17, 177-188

Sylvia DM (1988) Activity of external hyphae of vesicular-arbuscular mycorrhizal fungi. Soil Biol Biochem 20 (1), 39-43

Sylvia DM, Burks JN (1988) Selection of a vesiculararbuscular mycorrhizal fungus for practical inoculation of Uniola paniculata. Mycologia 80, 565-568

Tisserant B, Gianinazzi-Pearson V, Gianinazzi S, Gollote A (1992) In planta histochemical staining of fungal alkaline phosphatase activity for analysis of efficient arbuscular endomycorrhizal infections. Mycol Res 97 (in press)

Trouvelot A, Kough J, Gianinazzi-Pearson V (1986) Mesure du taux de mycorhization VA d'un système radiculaire. Recherche de méthodes d'estimation ayant une signification fonctionnelle. In : Mycorrhizae : Physiology and Genetics (Gianinazzi-Pearson V, Gianinazzi S, eds) INRA Press, Paris, 217-221

Vierheilig H, Ocampo JA (1989) Relationship between SDH-activity and VA mycorrhizal infection. Agric Ecosystems Environ 29, 439-442 